\title{
Irrigation frequency influences establishment of silvery thread moss (Bryum argenteum Hedw.) and rooting of creeping bentgrass (Agrostis stolonifera L.) on simulated golf greens
}

Eric M. Lyons, Katerina S. Jordan, lain T. James, Darra M. Hudner and Darragh McGowan

This is an Accepted Manuscript of an article published by Taylor \& Francis in Acta Agriculturae Scandinavica, Section B - Soil \& Plant Science on May 24, 2012, available online: https://www.tandfonline.com/doi/full/10.1080/09064710.2012.685179

Suggested Citation: Eric M. Lyons, Katerina S. Jordan, lain T. James, Darra M. Hudner \&Darragh McGowan (2012) Irrigation frequency influences establishment of silvery thread moss(Bryum argenteum Hedw.) and rooting of creeping bentgrass (Agrostis stolonifera L.) on simulated golf greens, Acta Agriculturae Scandinavica, Section B - Soil \& Plant Science, 62:sup1, 79-85, https://doi.org/10.1080/09064710.2012.685179 


\section{Irrigation frequency influences}

establishment of silvery thread moss (Bryum argenteum Hedw.) and rooting of creeping bentgrass (Agrostis stolonifera $L$.) on simulated golf greens

Eric M. Lyons ${ }^{1}$, Katerina S. Jordan'1, lain T. James ${ }^{2}$, Darra M. Hudner ${ }^{1,2}$ and Darragh McGowan ${ }^{1}$

Affiliation: 1 Department of Plant Agriculture, University of Guelph, Guelph, Canada, ${ }^{2}$ School of Applied Science, Cranefield University, Befordshire, UK

Abstract: The encroachment of moss on creeping bentgrass (Agrostis stolonifera L.) golf greens is a significant problem throughout the world. Although chemical control products for moss exist many are not registered for this use in Europe and Canada. As a result turfgrass managers must rely on cultural methods to manage moss encroachment. A survey of 15 golf courses in southwestern Ontario positively identified silvery thread moss (Bryum argenteum Hedw.) (STM) as the primary species of moss present. In order to determine the effects of irrigation practices on STM establishment two independent greenhouse experiments were conducted in which the quantity and frequency of irrigation were altered. Pots containing creeping bentgrass were inoculated with STM and irrigated at either $75 \%$ or $100 \%$ open pan evaporation (Eo) and at 1-, $2-$, 4-, or 7-day intervals. Volumetric water content was measured in the top $5.7 \mathrm{~cm}$ of the pots to confirm that changes in water availability were a result of irrigation practices. Between the two levels tested, irrigation quantity had no effect on the presence of STM. In the first experiment irrigation at 1-day and 2-day intervals had significantly more STM invasion than irrigation at 4- and 7-day intervals. In the second experiment point quadrat counts showed that irrigating at both 1-day and 2-day intervals resulted in significantly more STM and that the most moss was observed with the daily irrigation regime. Root data were also collected to determine the effect of irrigation practices on root mass. The daily irrigation treatments in both experiments had reduced root mass although in the first experiment only the root mass below $12 \mathrm{~cm}$ was lower. In the second experiment the total root mass was highest for the 4-day irrigation interval with the 2- and 7-day intervals having intermediate root mass and daily irrigation resulting in the least.

Keywords: Evapotranspiration, irrigation rate, putting greens, root mass, volumetric water content 


\section{Introduction}

Twenty years ago, silvery-thread moss (STM) (Bryum argenteum) was a minor nuisance weed on golf course putting greens (Taylor and Danneberger 1996). However, in the past 10 years the issue has expanded from a regional issue, primarily affecting the USA and Canada, to a global problem (Yelverton 2005). The issue has occurred in part as a result of changes to management practices of putting greens in response to increased demands by end users. These practices have created ideal conditions for STM. Putting green swards are habitually noncompetitive due to biotic and abiotic stresses placed on turfgrass plants by low mowing, rolling and traffic (Boesch and Mitkowski 2005). A high infestation of STM within a golf course green produces a silvery green coloured, softly textured carpet (Snow 1984), affecting both the functional and aesthetic quality of the green. If current management practices continue to favor STM in putting environments, the percentage of moss coverage will increase until a surface is deemed unusable (Boesch and Mitkowski 2005).

The recent increase in STM encroachment on putting greens is a much debated topic, and focuses on two key changes within golf course putting green management: (1) the removal of mercury-based fungicides/pesticides (Burnell et al. 2004, Boesch and Mitkowski 2005) for human health and safety reasons and (2) the pursuit of increased ball roll distance (BRD), commonly referred to as green speed (Boesch and Mitkowski 2005). The reduction in mowing heights to increase BRD on golf greens has been associated with a number of turfgrass health issues, including weed invasion (Kneebone et al. 1992). In a non-competitive sward STM will receive adequate light while thriving at mowing heights between 2.5 and $4 \mathrm{~mm}$ due to its short, stout, $1-3 \mathrm{~mm}$ plant height (Elridge 1998, Aceto et al. 2003).

One cultural practice that is often associated with moss invasion is irrigation (Suffern 2004). The encroachment of STM has been associated with the practice of overwatering grasses, as mosses are believed to be associated with stable, wet environments (Suffern 2004, Nelson 2007). In actuality, STM does not require a stable environment, and can invade areas of active erosion (Eldridge 1998) such as worn areas resulting from excess play, areas of repeated mower scalping and pitch marks. It 
is very successful in restricted niches and voids and is tolerant of extremes in both moisture availability and temperature (Hock et al. 2004). In recent years the desire to increase green speed has resulted in an attempt by golf course superintendents to keep the greens as dry as possible throughout the growing season. This has resulted in reduced irrigation rates but increased irrigation frequency, often achieved through syringing and light, frequent watering to maintain consistent conditions and keep the turfgrass alive (Guertal et al. 2005).

The objective of this research was to determine the effect of irrigation rate and frequency on the establishment of STM into simulated creeping bentgrass putting greens.

\section{Materials and methods}

In order to determine which species of moss were present on golf greens in southwestern Ontario, 43 samples from 15 golf courses throughout the region were collected and dried. All samples were positively identified as STM. Of the specimens collected, samples of active STM taken from Victoria West Golf Club, Guelph, ON in November 2005 and September 2009 were used for the first and second experiments, respectively.

The first greenhouse experiment was conducted during the summer of 2007 in a climate-controlled greenhouse located at a latitude of 40.79' $\mathrm{N}$ and longitude of $77.86^{\prime}$ W with natural light supplemented to ensure a minimum 12-hour photoperiod. The duration of the experiment was just under 3 months, commencing on May 212007 and concluding on August 14 2007. The second greenhouse experiment was conducted in the winter from November 22009 through February 182010 in the same climatecontrolled greenhouse. Prior to the initiation of the experiment $32 \mathrm{PVC}$ pots, measuring $38 \mathrm{~cm}$ deep and $7.5 \mathrm{~cm}$ in diameter (providing a surface area of $33 \mathrm{~cm}^{2}$ ), were constructed to mimic a golf green root zone. The pots were filled with $7.5 \mathrm{~cm}$ of pea gravel and overlaid with $30 \mathrm{~cm}$ of calcareous sand, both materials conforming to USGA specifications for golf greens (USGA Green Section Staff 2004). All of the pots were filled in $10 \mathrm{~cm}$ stages, using a moistened root zone that was vibrated and compacted 
through layers to ensure minimal settlement after initiation of the experiment. Once constructed each pot was watered to the point of saturation to further reduce the chance of settlement.

The pots in the first experiment were seeded with creeping bentgrass (Agrostis stolonifera L.) cultivar 'Penn A4' while the second experiment used cultivar 'L-93.' All pots were seeded at a rate of $5 \mathrm{~g} \mathrm{~m}^{-2}$. The grass in the pots was grown with enough irrigation to ensure germination and growth and the pots were fertilized weekly and mowed every 1 to 2 days to maintain a cutting height of $5 \mathrm{~mm}$. In the first experiment, three pots sustained water damage during the grow-in period due to a glasshouse malfunction. These pots were reseeded and upon the initiation of the treatment were deemed acceptably mature for inclusion. All of the reseeded pots were included in a fourth replica block to ensure that a failure would not jeopardize the experiment's success.

The STM samples chosen for the experiments were dried and stored at room temperature and then ground into a fine powder using an electric blade coffee grinder (Model: E160BY, Hamilton Beach, Southern Pines, NC, USA). On May 212007 (first experiment) and November 22009 (second experiment), each pot was uniformly inoculated with $1 \mathrm{~g}$ of STM. The watering program, which consisted of one of four watering frequencies (1-, 2-, 4-, and 7-day intervals) and two watering rates based on open pan evaporation $\left(E_{\circ}\right)\left(100 \% E_{o}\right.$ and $\left.75 \% E_{\circ}\right)$ also began on the same date. Three days prior to inoculation all pots were saturated and allowed to drain to ensure similar water content in all of the pots at the beginning of the experiment. To calculate Eo three Petri dishes with the same diameter of the lysimeters were placed on top of three empty lysimeters with a white background. Each day the amount of water loss from the Petri dishes was calculated by subtracting the initial weight of the water from the final weight. The average of the three dishes was then taken as Eo. The experiment was set up as a factorial design for a total of eight different irrigation treatments. All irrigation was supplied as de-ionized water applied using a battery operated hand-held sprayer (Cepia power sprayer, Saint Louis, MO, USA). The sprayer was calibrated daily to ensure that an accurate rate was applied. Care was taken when watering to ensure a consistent 
height was maintained (10 cm above the surface) such that the replicated spray pattern caused minimal surface disturbance to the moss while ensuring minimal leaf surface deflection and water loss from the surface of the pot.

All of the pots were maintained at a height of approximately $5 \mathrm{~mm}$ using hand scissors throughout the experiment. Lower heights could not be achieved as mowing below 5 $\mathrm{mm}$ could lead to moss and surface disturbance. Clippings were not removed, but allowed to remain within the canopy. The plants were mowed every 1-2 days depending on growth rate.

Fertility varied slightly between the two experiments. The first experiment was fertilized on May 25 and June 20 with $50 \mathrm{ml}$ of a fertilizer containing $1.98 \mathrm{mmol} \mathrm{L}^{-1} \mathrm{~N}, 0.123 \mathrm{mmol}$ $\mathrm{L}^{-1} \mathrm{P}$ and $0.713 \mathrm{mmol} \mathrm{L}^{-1} \mathrm{~K}$. Two additional fertilizer applications were made on July 6 and July 13 with $50 \mathrm{~mL}$ of a fertilizer containing $9.9 \mathrm{mmol} \mathrm{L}^{-1}$ of $\mathrm{N}, 0.615 \mathrm{mmol} \mathrm{L}^{-1} \mathrm{P}$ and $3.566 \mathrm{mmol} \mathrm{L}^{-1} \mathrm{~K}$. The fertilizer applications resulted in the equivalent of $3.8 \mathrm{~g} \mathrm{~N} \mathrm{~m}^{-2}$,

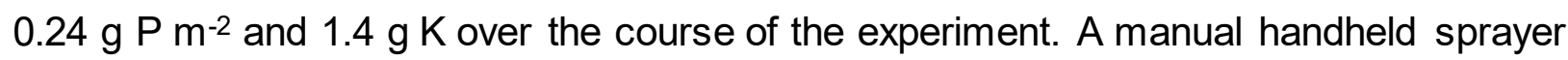
applied fertilizer in a fine mist foliar application. The second experiment was fertilized on December 8 and February 2 with $2.7 \mathrm{~g} \mathrm{~N} \mathrm{~m}^{-2}$ supplied by a 20-8-20 commercial fertilizer (Plant Products, Brampton, ON, Canada) for a total of $5.4 \mathrm{~g} \mathrm{~N} \mathrm{~m}^{-2}, 0.9 \mathrm{~g} \mathrm{P} \mathrm{m}^{-2}$ and $4.5 \mathrm{~g}$ $\mathrm{K} \mathrm{m}^{-2}$ over the course of the experiment.

\section{Data collection}

In the first experiment percent volumetric water content (WWC) was measured for 8 consecutive days from June 15 to 22 to confirm the effects of the irrigation treatments on water availability in the top of the root zone. All readings were taken with a Theta probe HH2 (Delta-T Devices, Cambridge, England) that measured WWC in the top 5.7 $\mathrm{cm}$ of the root zone. Measurements were taken at the same time each day just before irrigation was applied for that day.

Both experiments measured moss encroachment at canopy level in the intact pots and destructively at the conclusion of the experiment. In the first experiment percent cover was measured in July by overlaying an acetate sheet and marking points where moss was present. These acetate sheets were scanned and percent cover was calculated (Sigma-Scan, Systat Software, San Jose, CA, USA). In the second experiment percent 
cover was measured on February 16 by taking digital images and overlaying a $0.3 \mathrm{~cm}^{2}$ grid on the images. The percent cover was calculated as the percentage of squares that contained moss.

Plant tissue was harvested using a sharp knife and cutting the ground cover and rootzone material into four distinct portions. The canopy, including crowns, leaf tissue and shoots was removed along with a $0.5 \mathrm{~cm}$ slice of root zone material. The removal of the interface between shoot growth and root growth ensured that sub-surface root tissue weight was not adversely contaminated by stem tissue. Fresh weight of moss in the top portion was determined by separating the moss from the soil under running water using a fine mesh screen. The growing container root zones were then cut as follows: 0-3 cm, 3-12 cm, and below $12 \mathrm{~cm}$. Each section of roots was bagged, labeled, and refrigerated until roots could be separated from the soil material. Each section was washed under water using a 1-mm sieve. The washed samples were placed in a paper envelope and allowed to dry at $70^{\circ} \mathrm{C}$ for 24 hours. The dry weight of the material was then recorded. In the second experiment only two root sections were separated: 0-12 $\mathrm{cm}$ and below $12 \mathrm{~cm}$ based on the results of experiment one.

Both experiments were run as a complete randomized block design with four replications. Due to differences between experiments the data were analysed separately using the mixed model in JMP (SAS, Carey, NC, USA). Where significant differences existed, means separation was conducted as a Tukey's protected HSD at alpha $=0.05$.

\section{Results}

\section{Soil moisture}

The volumetric water content varied among the different frequencies within the weekly irrigation treatments (Figure 1). There were not consistent differences between the two different rates of $E_{o}$ in the top portion of the root zone. The average weekly irrigation rate for the $100 \%$ and $75 \%$ Eo treatments was $33 \mathrm{~mm}$ and $25 \mathrm{~mm}$ respectively. Soil in the 4- and 7-day interval treatments showed significant drying of the top $5.7 \mathrm{~cm}$ toward the end of the irrigation cycles. However, the plants continued to grow well in the 4-day 
irrigation frequency, suggesting there was adequate soil moisture at depth to support plant growth. Plants under the 7-day irrigation regime often looked wilted or dry by the fifth day following irrigation events. Soil in the daily and 2-day interval treatments had more consistent moisture at the surface of the root zone and often led to the highest quality creeping bentgrass canopies (data not shown).

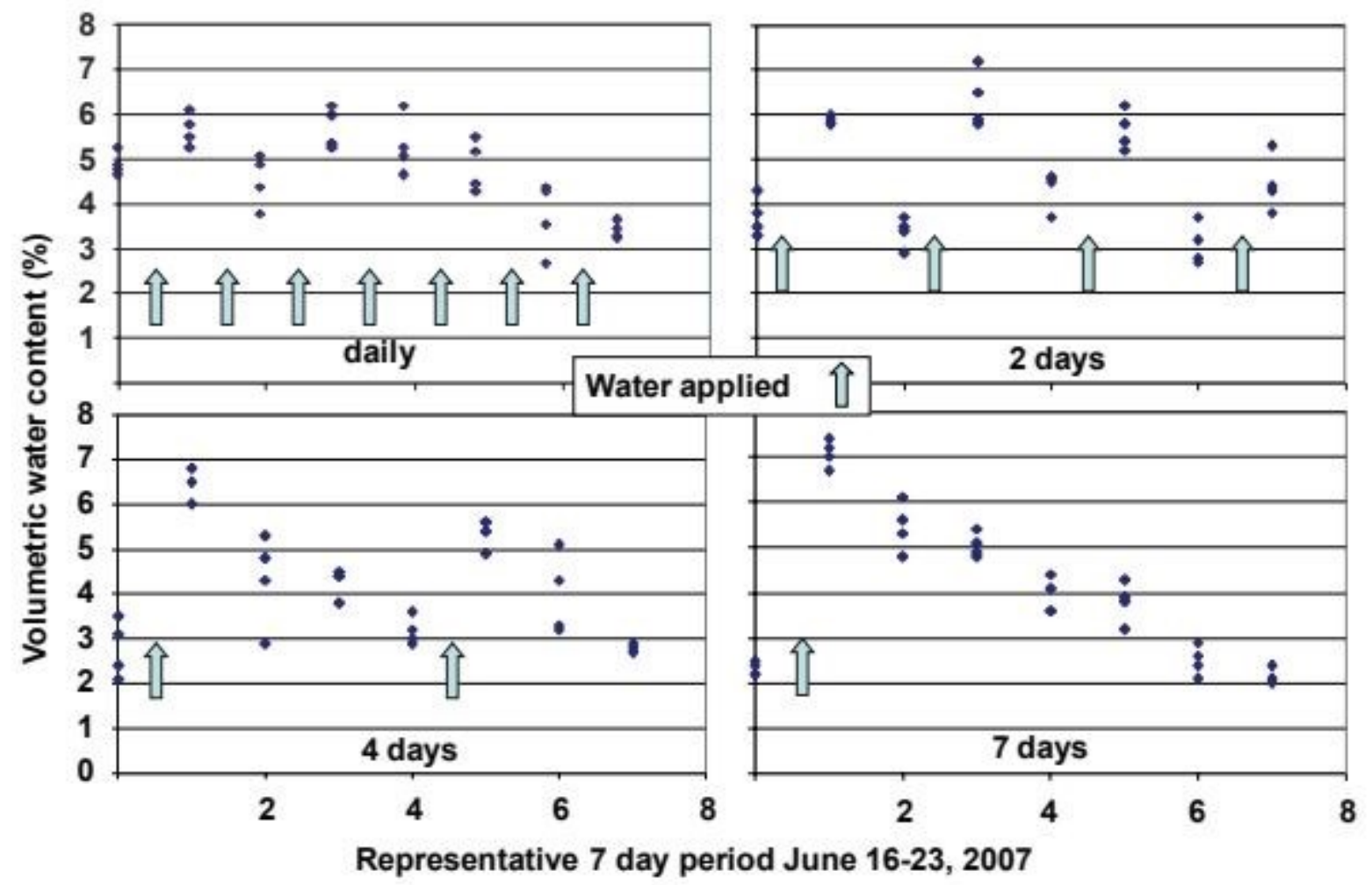

Figure 1. Volumetric water content of a representative 8-day period of pot watered with $100 \%$ of open pan evaporation as measured by a theta-probe in the top $5.7 \mathrm{~cm}$ of the root zone under daily, 2-, 4-, and 7-day irrigation frequencies. Arrows represent watering events in each respective treatment. Each point represents a single measurement with one measurement per pot per day

\section{Moss encroachment}

Although moss was measured differently between the two experiments similar results were observed. There were no differences between the $75 \%$ and $100 \% E_{o}$ treatments, however, a significant effect of irrigation frequency was observed. There were no significant interactions between rate and frequency and the data from the different irrigation rates were pooled (Figures 2-5). In the first experiment final moss counts were higher from the 1- and 2-day irrigation frequencies (Figure 2). The counts from the 4- 
and 7-day irrigation frequencies were very low, averaging only 2 and 1.65 moss leaflets per pot, respectively. In the second experiment the same separation occurred in the fresh weight measurements of the moss plants (Figure 3). Moss presence was higher in the 1- and 2-day irrigation frequency treatments than in the 4- and 7-day irrigation frequency pots. The percent cover of the moss plants was not significant in the first experiment where acetate sheets were overlaid on the pots and the incidence of moss was recorded. The size of the marks may have played a role in the precision of this measurement technique as many were very small. In the second experiment where the grid was overlaid onto digital images of the canopy differences were significant with daily irrigation ( $1.5 \%$ coverage) resulting in higher levels of moss than the 4 - and 7 -day irrigation frequency treatments that had no detectable moss in the photographs. The 2day irrigation frequency $(0.65 \%)$ was not different from either group (data not shown).

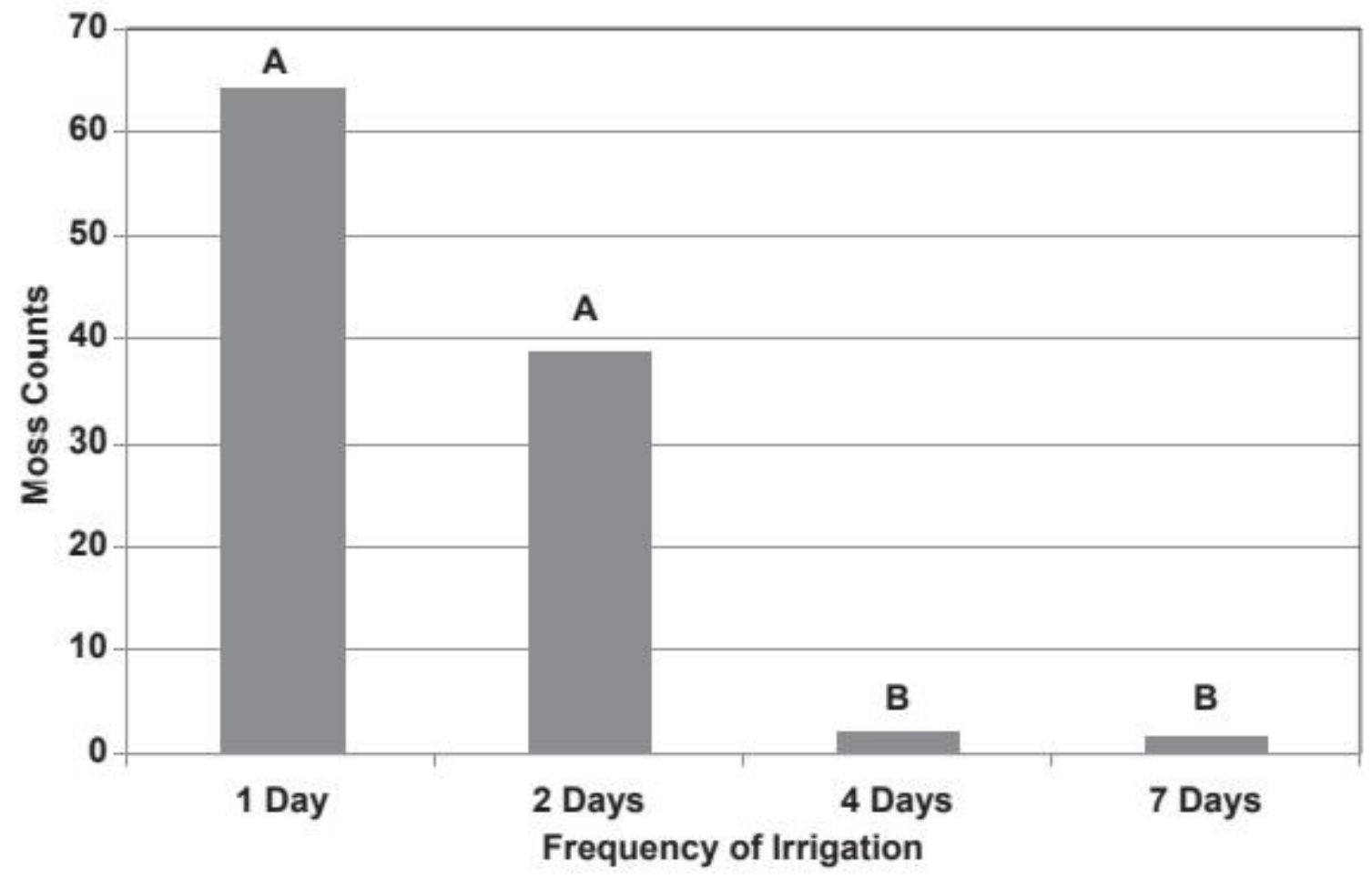

Figure 2. Counts of moss leaflets in a 7.5-cm diameter pot of creeping bentgrass under daily, 2-, 4-, and 7-day irrigation frequencies in the first of two experiments. Each bar represents an average of four replicates at two different irrigation rates $100 \%$ and $75 \%$ of open pan evaporation for a total of $n=8$. Bars with different letter are significantly different at alpha $=0.05$. 


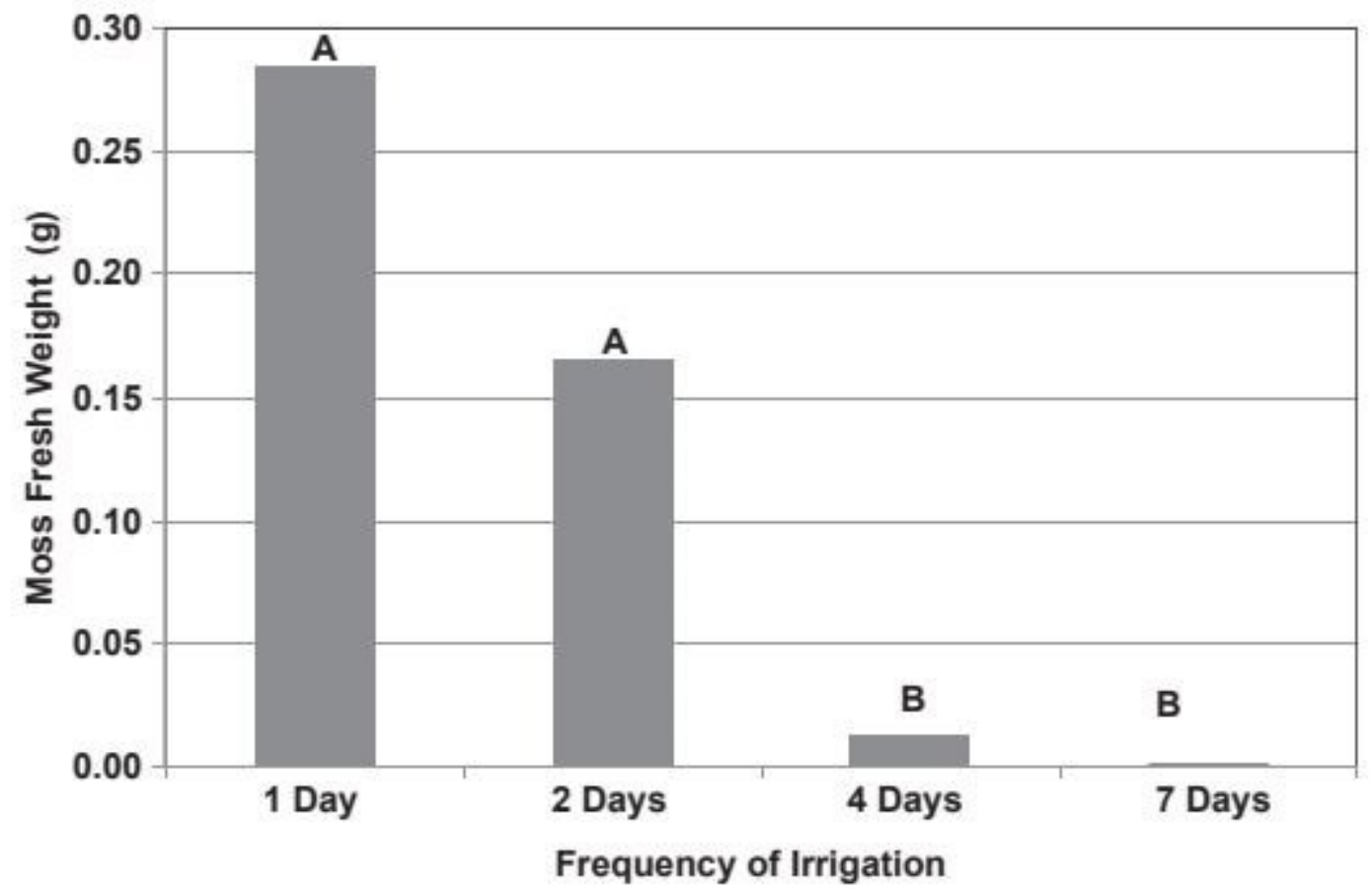

Figure 3. Fresh weight of moss leaflets in a $7.5-\mathrm{cm}$ diameter pot of creeping bentgrass under daily, 2-, 4-, and 7-day irrigation frequencies in the second of two experiments. Each bar represents an average of four replicates at two different irrigation rates $100 \%$ and $75 \%$ of open pan evaporation for a total of $n=8$. Bars with different letter are significantly different at alpha $=0.05$.

\section{Root mass}

As with moss encroachment, there were no differences in root mass between the two irrigation rates. However, irrigation frequency did have a significant effect on root mass. In the first experiment the only difference in rooting was found in the root mass below 12 $\mathrm{cm}$. More root mass was collected in the pots with the 7-day irrigation frequency as compared with the daily irrigation treatment (Figure 4). The second experiment showed significant differences in total root mass (Figure 5) and in the root mass from the upper section of the rootzone $(0-12 \mathrm{~cm})$ (data not shown). In both cases the 4-day irrigation frequency had the highest total root mass and the daily irrigation had the lowest. Both no difference in total root mass between the 2- and 7-day irrigation frequencies. 


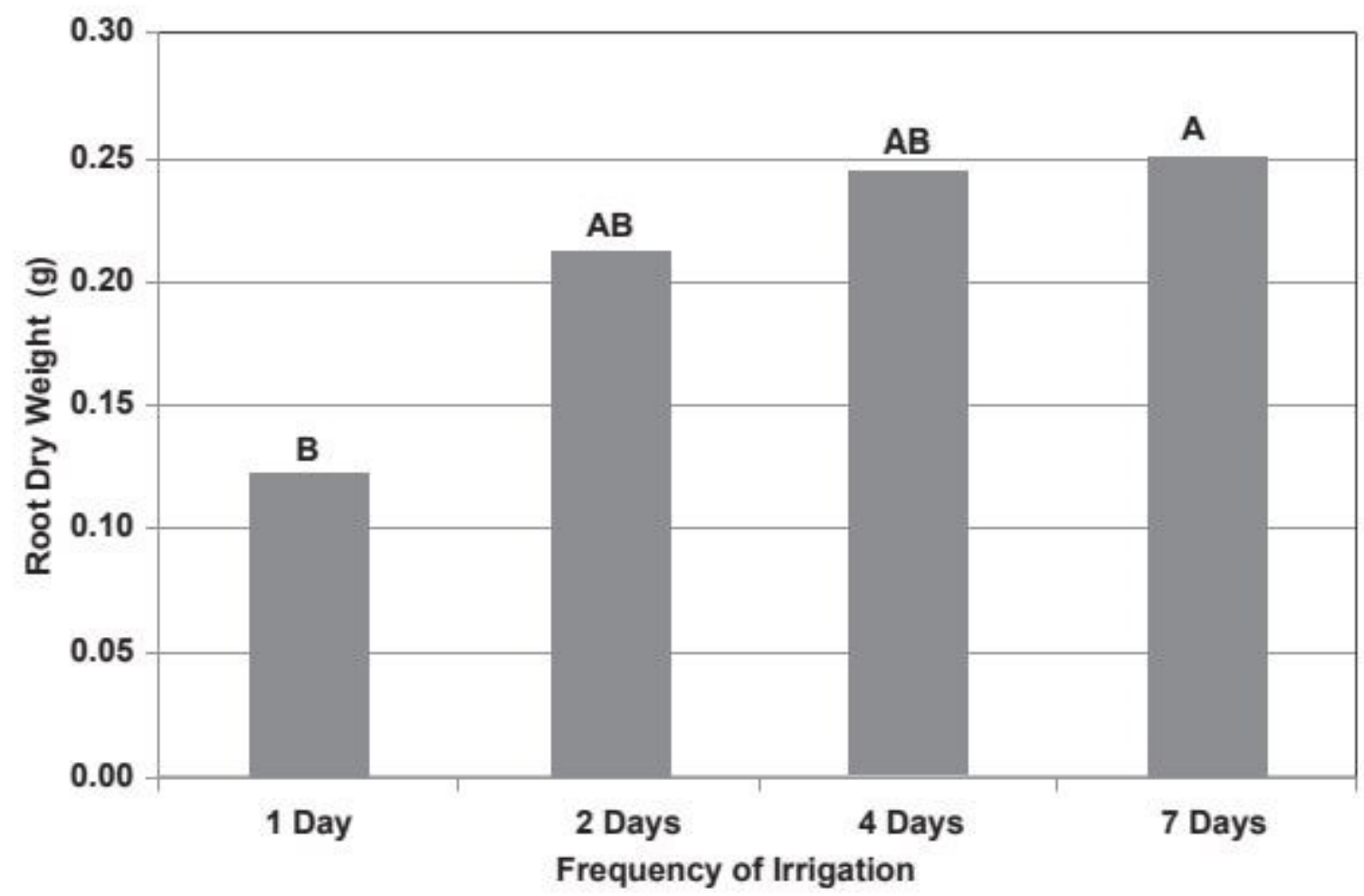

Figure 4. Dry root mass below $12 \mathrm{~cm}$ of depth in a $7.5-\mathrm{cm}$ diameter pot of creeping bentgrass under daily, 2-, 4-, and 7-day irrigation frequencies in the first of two experiments. Each bar represents an average of four replicates at two different irrigation rates $100 \%$ and $75 \%$ of open pan evaporation for a total of $n=8$. Bars with different letter are significantly different at alpha $=0.05$. 


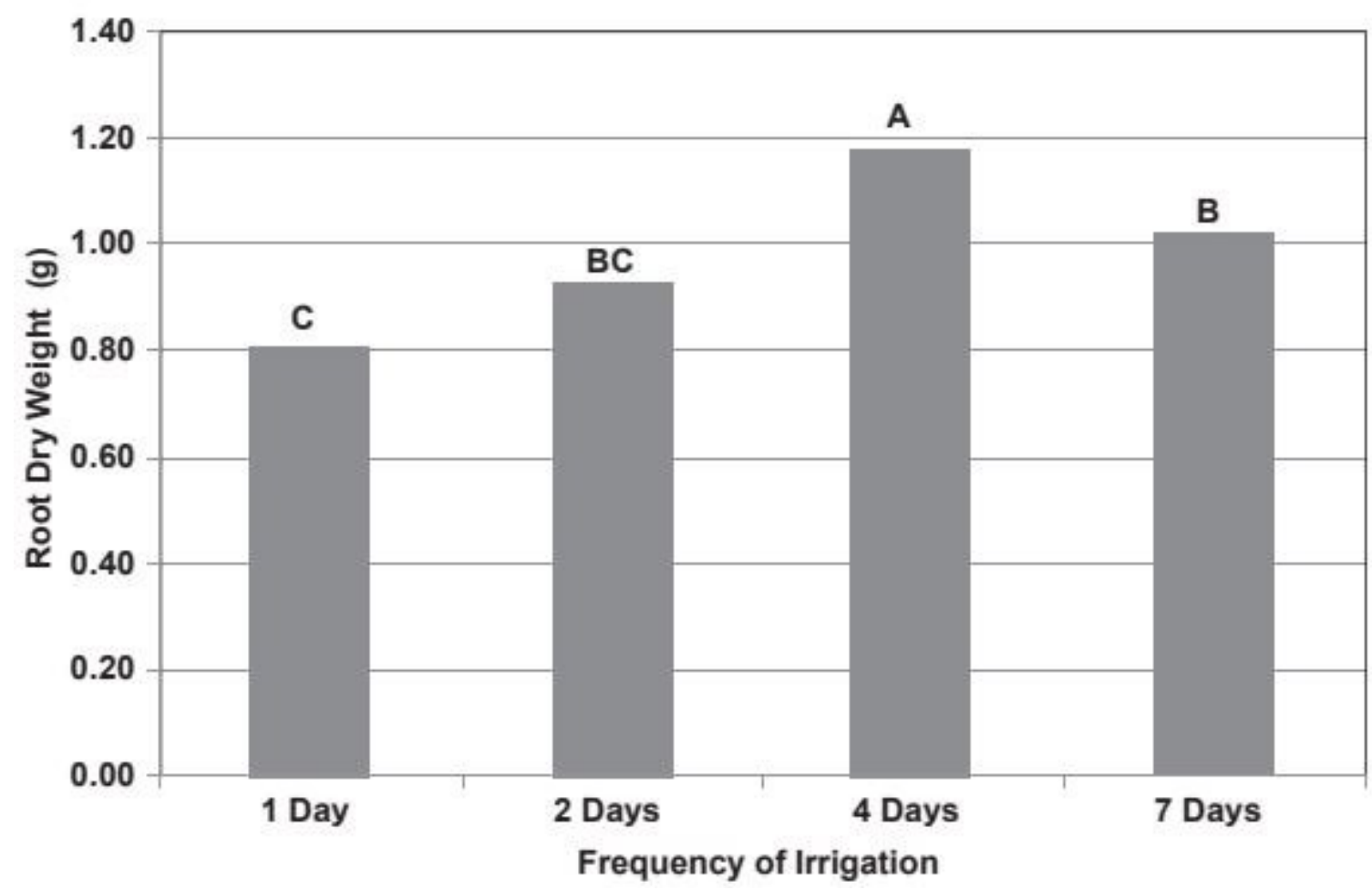

Figure 5. Total dry root mass in a 7.5-cm diameter pot of creeping bentgrass under daily, 2-, 4-, and 7-day irrigation frequencies in the second of two experiments. Each bar represents an average of four replicates at two different irrigation rates $100 \%$ and $75 \%$ of open pan evaporation for a total of $n=8$. Bars with different letter are significantly different at alpha $=0.05$.

\section{Discussion}

The current research presented shows that irrigation frequency impacts STM establishment into simulated creeping bentgrass putting greens. Silvery thread moss is an ectohydric species of moss and these moss species predominate on hard, impermeable and often nutrient-poor substrata (e.g. rock surfaces and bark) (Proctor 1981). Desiccation tolerance is very common amongst bryophytes, but varies among different species. The highest degree of tolerance is seen in mosses found on dry, sun exposed rock surfaces and comparable habitats that experience extreme desiccation (Proctor and Tuba the 4- and 7-day irrigation frequency treatments produced a higher root mass than daily irrigation, although there was 2002). For example STM can survive desiccation for two years before resuming normal metabolic functions (Richardson 1981). When remoistened, normal metabolism returns within minutes or hours. The ability to dry out completely and regain metabolic function quickly increases the 
competiveness of STM when water becomes available at the surface of the root zone each morning.

Our research showed that creeping bentgrass turf had less moss establish when irrigated every 4- or 7-days compared with a daily irrigation regime. Water from the lessfrequent irrigation treatments would reach deeper into the root zone as a greater amount was applied at each irrigation event to replace loss due to evapotranspiration. The water deeper in the soil profile would most likely favor creeping bentgrass over the STM because the creeping bentgrass would have access to water through its roots whereas the STM would be experiencing the dry surface conditions (Lyons et al. 2011). In addition, research has shown that root count and root length in the desirable creeping bentgrass will increase in response to reduced available moisture in the upper portion of the soil profile (Fu and Dernoeden 2009).

Other studies have also shown that irrigation frequency impacts root length density in creeping bentgrass cultivars (Jordan et al. 2003). Our results are similar in that with the 1- and 2-day irrigation frequency treatments less total root mass was produced than with either a 4-day or a 7-day irrigation frequency regime. Although the first experiment showed no differences in overall root mass significant differences were observed in root mass below $12 \mathrm{~cm}$ of depth. When irrigation is applied more frequently the plants respond with less root mass suggesting that roots are not as necessary with frequent irrigation.

\section{Conclusion}

This study suggests that irrigation frequency, rather than quantity, is an important factor in the establishment and competitiveness of STM in a creeping bentgrass golf course putting green. This study may be limited, however, in that the two irrigation rates examined may have been in excess of a deficit irrigation program. In areas where moss is prevalent, our recommendations are for golf course managers to reduce their irrigation frequency and to ensure that any supplemental hand-watering allows for moisture to be applied only to the plant roots rather than the surface of the rootzone. By increasing moisture at depth in the rootzone and decreasing moisture on the surface of 
the soil, the turfgrass species become more competitive than the moss due to the presence of a root system in the turfgrass plants.

\section{References}

Aceto, M., Abollino, O., Conca, R., Malandrino, M., Mentasti, E., \& Sarzanni, C. (2003). The use of mosses as environmental metal pollution indicators. Chemosphere, 50, 333-342.

Boesch, B. P., \& Mitkowski, N. A. (2005). Chemical methods of moss control on golf course putting greens. Applied Turfgrass Science. Available at: http://www.plantmanagementnetwork. org/pub/ats/review/2005/moss/ (Accessed 27 December 2011).

Burnell, K. D., Yelverton, F. H., Neal, J. C., Gannon, T. W., \& McElroy, J. S. (2004). Control of silvery-thread moss (Bryum argenteum Hedw.) in creeping bentgrass (Agrostis palustris Huds.) putting greens. Weed Technology, 18, 560-565.

Eldridge, D. J. (1998). Distribution and floristics of mossand lichen-dominated soil crusts in a patterned Callitris glaucophylla woodland in eastern Australia. Acta Oecologica, 20(3), 159-170.

Fu, J., \& Dernoeden, P. H. (2009). Creeping bentgrass putting green turf responses to two summer irrigation practices: Rooting and soil temperature. Crop Science, 49, 1063-1070.

Guertal, E. A., van Santen, E., \& Han, D. Y. (2005). Fan and syringe application for cooling bentgrass greens. Crop Science, 45, 245-250.

Hock, Z., Szovenyi, P., \& Toth, Z. (2004). Seasonal variation in the bryophyte diaspore bank of open grasslands on dolomite rock. Journal of Bryology, 26, 285-292.

Jordan, J. E., White, R. H., Vietor, D. M., Hale, T. C., Thomas, J. C. \& Engelke, M. C. (2003). Effect of irrigation frequency on turf quality, shoot density, and root length density of five Bentgrass Cultivars. Crop Science, 43, 282-287.

Kneebone, W. R., Kopec, D. M., \& Mancino, C. E. (1992). Water requirements and irrigation. In D. V. Waddington, R. N. Carrow, \& R. C. Shearman (Eds.), Turfgrass Agronomy Monograph 32. Madison, WI: ASA.

Lyons, E. M., Snyder, R. H., \& Lynch, J. P. (2011). Root distribution and tiller densities of creeping bentgrass cultivars and greens-type annual bluegrass cultivars in a putting green. Hort Science, 46, 1411-1477.

Nelson, M. (2007). Of moss and men. USGA Green Section Record, 45, 12-15.

Proctor, M. C. F. (1981). Physiological ecology of bryophytes. Advances in Bryology, 1, 79-166. 
Proctor, M. C. F., \& Tuba, Z. (2002). Poikilohydry and homoiohydry: antithesis or spectrum of possibilities? Tansley review no. 141. New Phytologist, 156, $327-$ 349.

Richardson, D. H. S. (1981). The biology of mosses. Halsted Press, New York City, NY, USA.

Snow, J. T. (1984). A rolling stone ... and healthy turf. USGA Green Section Record, 22, 7-9.

Suffern, L. (2004). The menace of moss: A blight on turf. Green Master, 39, 22-24.

Taylor, J., \& Danneberger, K. (1996). Moss on greens: when the rolling stone stops. Golf Course Management, 64, 53-56.

USGA Green Section Staff (2004). USGA Recommendations for a method of putting green construction [Online]. Available at http://www.usga.org/course_care/articles/construction/ greens/USGARecommendations-For-A-Method-Of-Putting Green-Construction(2)/ (Accessed 27 December 2011).

Yelverton, F. (2005). Managing silvery thread moss in creeping bentgrass greens. Golf Course Management, 73, 103-107. 